\title{
AN INTERNATIONAL COMPARISON OF YOUTH (AGED 16 TO 19) IN THE SOUTHERN BALTIC REGION: THE SITUATION IN SCHOOLS
}

\author{
Giedré StraksienE $\dot{1}^{1}$, Aleksandra Batuchina ${ }^{2}$ \\ giedre.straksiene@ku.lt; Aleksandra.ro@gmail.com \\ Klaipėda University (Lithuania)
}

\begin{abstract}
This study presents an internationally (cross-border) representative picture of the school environment, atmosphere and action taken by schools aiming at the involvement of students in their actions. The study was conducted within the framework of the CaSYPoT project (Capacity Building for Strategic Youth Policy and Transnational Cooperation) under the Interreg South Baltic Programme 2014-2020 (Project No STHB.05.01.00-SE-0024/15). The main aim of the CaSYPot project was to encourage young people to get involved in local democracy, and to present youth as a resource in the development of society. Furthermore, for the design and implementation of the southern Baltic youth strategy, it is important to gain an insight into the current situation regarding the environment in schools. One section of this survey was addressed to the situation of youth in schools. The international survey for the CaSYPoT project was conducted among 1,593 students, in six towns in the southern Baltic region, in Sweden, Poland, Russia and Lithuania, from April to June 2017. The project partner's towns carried out a survey on teenagers aged 16 to 19, identifying their needs and problems in school, and providing comparable data. The questionnaire contained questions addressing young people's well-being and atmosphere of safety, the climate at school, and their experience in getting involved in the work of the school and their influence on decision making. To sum up, the study describes the current situation in schools, which is essential for the development and evaluation of future policies and actions. The survey covers a wide range of student opinions on school, and begins with a summary of the key findings drawn from an analysis of the survey, and strategic recommendations for the future.
\end{abstract}

KEY WORDS: school, students, youth, education, strategy, CaSYPoT project.

JEL CODES: H51, H52, H53, H75

DOI:

\section{Introduction}

The United Nations Youth Strategy 2030 presented on 24 September 2018 at a high-level event at the United Nations in New York declares that 'young people are also facing incredible challenges and even lifethreatening risks $[\ldots]$ and these arise when accessing their rights, including to quality education, health care and decent work' (Youth 2030. Working with and for young people, 2018:4). The priority of this strategy is to support greater access by young people to quality education and health services. This means ensuring universal access to quality education, developing and delivering quality and inclusive education for young people that is learner-centred, adopts a lifelong learning approach, is relevant to their lives and the social, economic and environmental needs of their communities, and promotes sustainable lifestyles and sustainable development (Youth 2030. Working with and for young people, 2018:10-11). According to the statistical

1 Giedrė Strakšienė, PhD at Klaipėda University, Faculty of Social Sciences and Humanities, Centre for Social Change.

Research interests: science communication, science and art communication, development of communication.

E-mail: giedre.straksiene@ku.lt

2 Dr Aleksandra Batuchina, lecturer at the Centre for Social Geography and Regional Studies (Faculty of Social Sciences and Humanities, Klaipeda University).

Research interests: qualitative research methodology, phenomenology methodology, migration studies.

E-mail: aleksandra.ro@gmail.com 
data, approximately 62 million adolescents of lower secondary school age remain out of school (Data for the Sustainable Development Goals, 2018). As is stated in the document, leaving school early is linked to unemployment, social exclusion, poverty and poor health. There are many reasons why some young people give up education and training prematurely: personal or family problems, learning difficulties at school, or a fragile socio-economic situation. The way the education system is set up, the school environment (climate), and teacher-student relations are also important factors (Early School Leaving, EU).

The health, education and employment issues confronting youth today in the southern Baltic region are highly interrelated. There is a need for a comprehensive multi-sectoral youth policy to address these inequalities, and to help guide public and private sector investment in the areas of education, vocational training, health services and information. EU countries have committed themselves to reducing the numbers of early school leavers to less than $10 \%$ by 2020 . The educational achievements of young people are essential for the employment prospects of every young person. This is important for the growth of our economy and for social cohesion, especially at a time when the current financial and economic crisis is having a serious impact on young people and their families. Investing in education helps to break the cycle of deprivation and poverty that leads to the social exclusion of too many young people across Europe (Reducing early school leaving: Key messages and policy support. Final Report of the Thematic Working Group on Early School Leaving, 2013). Because of the importance of individual perceptions, researchers and local actors often assess how students feel about their school. Surveying the youth situation in Lithuania during the past year, researchers indicate a lack of motivation among youth to express an interest in their prospects, and a declining interest in their studies (Galimybių studija 'Klaipèdos jaunimo tyrimas', 2015).

Education for youth is a medium through which they can realise their potential. Young people should be equipped with the best possible education, and given favourable conditions, through the attainment of skills, to be an asset to the community, and that way contribute actively to the development of the community, for they are essential elements of society. In this globalised and knowledge-based world, young people should be given the opportunity to contribute to society by fulfilling their potential. Young people should be taught about the main issues facing our world, and should be encouraged to get involved through activism. Young people need to be educated in the roles they play in the global community.

The researcher A. Loukas (2007) states that the school environment (climate) is a leading factor in explaining student learning and achievement. The research shows that student perceptions of the school climate affect academic motivation. Increasingly, research is showing that perceptions of the school atmosphere also influence students' behavioural and emotional problems. According him (Loukas, 2007), the school environment (climate) is a multidimensional construct, which includes physical, social and academic dimensions. The physical dimension includes the appearance of the school building and its classrooms, the school's size and the ratio of students to teachers in the classroom, the order and organisation of classrooms in the school, the availability of resources, and safety and comfort. The social dimension covers the quality of interpersonal relationships between students and teachers, the equitable and fair treatment of students by teachers, the degree of competition and social comparison between students, and the influence to which students, teachers and school staff contribute to decision-making at their school. The last one is the academic dimension, which includes the quality of instruction, teachers' expectations of students' achievements, and monitoring students' progress and reporting the results to students and their parents. Furthermore, effective teaching and learning are the result of complex group and psychological processes. However, the precise organisational factors and psychological mechanisms behind these processes are still under investigation. Identifying the means to improve students' learning outcomes remains the subject of continuous academic inquiry, and a key objective of governmental and international bodies. In consequence, an immense body of work centred on the construct of the 'school climate' has emerged. The school environment (climate) refers to the social characteristics of a school, in terms of the relationships between students and teachers, the emphasis on learning and teaching, values and norms, and shared approaches and practices (A. Loukas, What is school climate?, 2007).

The project 'Capacity Building for Strategic Youth Policy and Transnational Cooperation' (CaSYPoT) was implemented under the Interreg South Baltic Programme 2014-2020 (Project No STHB.05.01.00- 
SE-0024/15) by partners from Sweden (Emmaboda, Calmar Regional Council, Linnaeus University), Poland (the Association of Polish Communes Baltic Euroregion, the city of Slupsk, the University of Gdansk), Russia (the Agency for Youth Affairs of the Kaliningrad Region, the towns of Svetlogorsk and Gusev, Immanuel Kant Baltic Federal University), and Lithuania (Klaipeda University). The survey aimed to investigate the conditions for young people in six towns in the southern Baltic region. The partner towns carried out a survey of teenagers aged 16 to 19 , identifying their needs and problems in school, and providing comparable data. A number of assessment instruments are available for examining student perceptions of the school climate, but the survey was developed in Sweden, and later adapted to the national contexts of the countries participating in the project. The results were analysed by universities, and compared between the countries. Based on the results, a joint knowledge-based youth strategy was created in the ERB and in participating towns. Additionally, the findings from the survey provide a glimpse of how students feel about certain dimensions of the school environment (climate), and allow the school community to take action to improve their quality.

The aim of the study was to analyse the results of the survey on the situation of students in schools, their opinions, and their views of their present and future situation and the society where they live, the southern Baltic region. The plan is to compare results, and to make conclusions and assumptions that can be used when identifying various needs, designing appropriate action plans and interventions in relation to youth policy in education.

Research methods: review of the literature, analysis of survey research (questionnaire) and basic data, descriptive statistics.

For the purpose of the study, the following theoretical concepts were identified, in an attempt to contextualise and understand the interdependent relationship between youth and the specific school contexts and positions in which they operate.

As was mentioned before, the survey was inspired by the Swedish LUPP survey (16 to 19-year-old youth questionnaire, Lupp [Hansén, C. Skålmedal, J. 2015]), but it was modified to enable comparisons with six towns in the southern Baltic region. Working with researchers from Linnaeus University, the on-line survey instrument was adopted to assess the situation in general of youth in the towns. The questionnaire consisted of several sections, which covered the following topics: free time, school, health, family, attitude to issues of social development and security, plans for the future or migration. The School section covered questions aimed at exploring how youth see themselves in school, their norms and environment (climate) in school, for school is one of the places where young people spend most of their time on a daily basis. We were particularly interested in examining positive and negative factors in school, looking at them from a student's perspective. Therefore, the researchers explored students' thoughts and feelings in relation to their motivation and engagement.

Respondents and organisation of the survey. The survey was completed by youth aged 16 to 19 from six towns. In total, there were 1,593 respondents from four countries (six towns) in the Baltic Sea region: Sweden (Emmaboda), Poland (Slupsk and Bartoszyce), Russia (Svetlogorsk and Gusev), and Lithuania (Klaipeda). The margin of sample error for the study is $+/-2.5$ percentage points. Seeking to encourage participation in the research, schools were assured anonymity and confidentiality. The survey was carried out from April to June 2017.

\section{Summary of the results}

The international survey asked youths from Sweden (Emmaboda), Poland (Bartoszyce, Slupsk), Russia (Gusev, Svetlogorsk), and Lithuania (Klaipeda) dozens of questions on their attitude towards the school situation. This section provides an overview of the key analytical points of the survey. Our analysis of the survey data identifies key points about student attitudes towards the school environment (climate) that indicate how they feel in school, how they can influence their studies, and on decision making in the school, and also how they can strengthen their commitment to the school community. 


\subsection{School orientation and programmes}

The youths who participated in the survey were from various educational institutions (see Fig.1).

\begin{tabular}{|c|c|c|c|c|c|c|c|c|c|c|c|c|}
\hline & \multicolumn{2}{|c|}{ Klaipėda } & \multicolumn{2}{|c|}{ Gusev } & \multicolumn{2}{|c|}{ Svetlogorsk } & \multicolumn{2}{|c|}{ Bartoszyce } & \multicolumn{2}{|c|}{ Slupsk } & \multicolumn{2}{|c|}{ Emmaboda } \\
\hline & $\%$ & Number & $\%$ & Number & $\%$ & Number & $\%$ & Number & $\%$ & Number & $\%$ & Number \\
\hline Upper secondary school & & & 64 & 157 & 71 & 51 & 37 & 69 & 23 & 157 & & \\
\hline Vocational & 22 & 101 & 33 & 81 & 19 & 14 & 1 & 1 & 13 & 88 & 34 & 46 \\
\hline $\begin{array}{l}\text { Preparation for higher educa- } \\
\text { tion }\end{array}$ & 75 & 344 & & & & & & & & & 60 & 81 \\
\hline Technical school & & & & & & & 15 & 27 & 55 & 371 & & \\
\hline Other orientation & 3 & 16 & 2 & 2 & 3 & 2 & & & & & 6 & 8 \\
\hline Lower secondary school & & & & & & & 34 & 64 & 0 & 2 & & \\
\hline $\begin{array}{l}\text { Profiled upper secondary } \\
\text { school }\end{array}$ & & & & & & & 13 & 25 & 8 & 55 & & \\
\hline University & & & 2 & 2 & 7 & 5 & & & & & & \\
\hline Total & & 461 & & 246 & & 72 & & 186 & & 673 & & 135 \\
\hline
\end{tabular}

Fig. 1. School orientation (percentages, numbers).

Source: CaSYPoT project website: http://casypot.eu/project/.

In the results about school orientation, we can see great differences between cities (in some cases, the differences are between districts). It is worth mentioning that there are differences between school types in the participating countries. Both, in Klaipeda and Emmaboda, participants came from vocational schools, or were preparing for higher education or another direction. In both these cities, the vast majority were preparing for higher education (in Klaipeda $75 \%$ and Emmaboda 60\%), and only a few (Klaipeda 3\%, Emmaboda $6 \%$ ) for other directions. In the other countries, some school types were added due to the peculiarities of the local educational systems. In Russia (Gusev and Svetlogorsk), the following educational levels were included: upper secondary school, vocational, university, and others, where the majority belonged to the upper secondary school level (Gusev 64\%, Svetlogorsk 71\%), a smaller part vocational (Gusev $33 \%$, Svetlogorsk $19 \%$ ), just few to university (Gusev 2\%, Svetlogorsk 7\%), and another direction (Gusev 2\%, Svetlogorsk 2\%). In Poland: upper secondary school (Slupsk 23\%, Bartoszyce 37\%), vocational (Slupsk 13\%, Bartoszyce 1\%), technical school (Slupsk 15\%, Bartoszyce 55\%), lower secondary school (Slupsk 0\%, Bartoszyce $34 \%$ ), profiled upper secondary school (Slupsk 8\%, Bartoszyce 13\%). As we can see from the Polish figures, the distribution of participants from this country was quite uneven.

Gender differences show an interesting distribution. Firstly, in all the cities, we can see more or less equal numbers of girls and boys among the respondents. Svetlogorsk stands out with a clear majority of girls (67\% girls, 33\% boys). However, this difference is insignificant. Moreover, in Sweden, a few respondents identified themselves as a third gender, and even though this percentage is not high, it cannot be omitted. Analysis of the different countries and school orientations shows that the representation of boys and girls is uneven, as, for instance, among the Klaipeda respondents, where $81 \%$ in the 'other direction' were boys, while in Gusev and Svetlogorsk $100 \%$ in this direction were girls. However, such disproportions cannot be analysed, due to the fact that these groups are not homogeneous. In seeking to analyse the differences, we also need to know what is behind the word 'other'. 


\begin{tabular}{|c|c|c|c|c|c|c|c|c|c|c|c|c|c|}
\hline \multirow{3}{*}{\begin{tabular}{|l|} 
B1. What ori \\
H1. Gender
\end{tabular}} & \multicolumn{2}{|c|}{ Klaipėda } & \multicolumn{2}{|c|}{ Gusev } & \multicolumn{2}{|c|}{ Svetlogorsk } & \multicolumn{2}{|c|}{ Bartoszyce } & \multicolumn{2}{|c|}{ Slupsk } & \multicolumn{3}{|c|}{ Emmaboda } \\
\hline & your & chool 1 & rogran & ime ha & ve? $(\%$ & & & & & & & & \\
\hline & Boys & Girls & Boys & Girls & Boys & Girls & Boys & Girls & Boys & Girls & Boys & Girls & other \\
\hline Upper secondary school & & & 44 & 56 & 38 & 62 & 38 & 62 & 42 & 58 & & & \\
\hline Vocational & 50 & 50 & 43 & 57 & 33 & 67 & 100 & 0 & 91 & 9 & 42 & 55 & 3 \\
\hline $\begin{array}{l}\text { Preparation for higher } \\
\text { education }\end{array}$ & 52 & 48 & & & & & & & & & 42 & 52 & 6 \\
\hline Technical school & & & & & & & 85 & 15 & 43 & 57 & & & \\
\hline Other orientation & 81 & 19 & 0 & 100 & 0 & 100 & & & & & 20 & 30 & 30 \\
\hline Lower secondary school & & & & & & & 51 & 50 & 100 & 0 & & & \\
\hline $\begin{array}{l}\text { Profiled upper secondary } \\
\text { school }\end{array}$ & & & & & & & 28 & 72 & 29 & 71 & & & \\
\hline University & & & 100 & 0 & 33 & 67 & & & & & & & \\
\hline Total $\%$ & 53 & 47 & 45 & 55 & 33 & 67 & 49 & 51 & 51 & 49 & 41 & 53 & 6 \\
\hline
\end{tabular}

Fig. 2. Gender distribution at various schools (percentages).

Source: CaSYPoT project website: http://casypot.eu/project/.

Remarks. 1. The percentage shows the representation of boys and girls at a chosen school (among respondents in that school). 2. The results are presented omitting missing (blank) and don't know answers.

1.2. Illness and disabilities among young people

A comparison of students in terms of illness and disability shows (Fig. 3) that the vast majority had no illness or disability which was not temporary.

\begin{tabular}{|l|l|l|l|l|l|} 
Klaipėda & Gusev & Svetlogorsk & Bartoszyce & Slupsk & Emmaboda \\
\hline
\end{tabular} H2. Do you have any illness or disability which is not temporary and which means that you have difficulty participating in various activities, such as at school, with friends, or during your leisure time? (Yes/ No).

B1. School programme.

\begin{tabular}{|c|c|c|c|c|c|c|c|c|c|c|c|c|}
\hline Numbers & Yes & No & Yes & No & Yes & No & Yes & No & Yes & No & Yes & No \\
\hline Upper secondary school & & & 16 & 112 & 4 & 33 & 7 & 59 & 28 & 97 & & \\
\hline Vocational & 18 & 63 & 12 & 49 & 2 & 6 & 0 & 0 & 8 & 63 & 5 & 31 \\
\hline Preparation for higher education & 26 & 237 & & & & & & & & & 4 & 65 \\
\hline Technical school & & & & & & & 5 & 22 & 37 & 282 & & \\
\hline Other orientation & 0 & 7 & 1 & 1 & 0 & 1 & & & & & 1 & 3 \\
\hline Lower secondary school & & & & & & & 7 & 52 & 0 & 2 & & \\
\hline Profiled upper secondary school & & & & & & & 3 & 19 & 11 & 30 & & \\
\hline University & & & 0 & 1 & 0 & 3 & & & & & & \\
\hline Total, \% & 11 & 76 & 14 & 47 & 11 & 80 & 12 & 84 & 14 & 76 & 8 & 83 \\
\hline
\end{tabular}

Fig. 3. School orientation and illnesses or disabilities (numbers).

Source: CaSYPoT project website: http://casypot.eu/project/.

Remark 1. The results are presented omitting missing (blank) and don't know answers. 2. Answers are presented in even numbers. 
As we can see in the results from Klaipeda, $76 \%$ of students had no illness or disability, and only $11 \%$ had (the results are similar in the other cities). Interesting statistical data can be seen in Gusev, where 39\% of respondents did not want to answer the question about illness or disability, which makes it hard to analyse the results.

\subsection{Situation and environment (climate, atmosphere) in schools}

A positive school atmosphere is essential for students to learn and develop. Previous research outcomes (Galimybių studija „Klaipedos jaunimo situacijos tyrimas', 2015; Jaunimo situacijos Kauno mieste tyrimas, 2011; Liukinevičiene, 2011 and others) show that a positive atmosphere in school improves student academic achievements and leads to greater self-esteem. Creating a positive classroom atmosphere takes an effort on the part of the teacher and students. The survey includes questions concerning the students' experience of the school environment (climate). There are themes in the survey concerning their well-being, social relations and recognition in school, as well as cooperation between teachers, school staff and students.

The question 'How well do you think these apply to your school?' presents the general atmosphere in school and how students experience it. The question consists of 13 statements. For the analysis, the answer 'Don't know' was not taken into account, while others were combined together: 'not true at all' and 'somewhat true', 'largely true' and 'completely true'.

The first statement 'I enjoy the atmosphere in my school' shows more or less the same results in all the cities. However, in Klaipeda and Svetlogorsk, $55 \%$ of respondents enjoy the atmosphere in school completely or say it is 'largely true'. In Svetlogorsk, $40 \%$ stated that it is 'not true at all' or only 'somewhat true', while in Emmaboda, the largest majority (85\%) completely or largely enjoy the atmosphere in school. Invariably, there are two prevailing cultures in any school: adult culture and student culture. These two cultures naturally dictate and determine different behaviours, unwritten rules and codes of conduct. They also come with a set of expectations, which for the most part are incongruous and incompatible with each other. That is to say, young people do not understand the pressures of being an adult working in a school, and adults have largely forgotten what it is like to be a young person.

The second statement 'Bullying occurs in my school' gives different results. From Figure 4, we can see that the highest percentage of students who say that bullying does not occur in their school are from Svetlogorsk (73\%) and Slupsk (72\%). The results from Gusev (68\%) and Bartoszyce (67\%) are a little bit lower. However, the situation is different in Sweden (57\% of the respondents marked 'not true' or 'somewhat true'), even though a very small part (10\%) marked 'completely true' and 'largely true'. From the statistical data, we can see a threatening situation in Klaipeda, where $44 \%$ of students marked 'completely true' and 'largely true', and only $43 \%$ marked 'not true' or 'somewhat true' about bullying in school. This raises some questions about the bullying situation among participants in Klaipeda's schools. Very similar results can be seen among the answers to the statement about racism, where we can see Klaipeda again as more problematic than the others (33\% marked 'completely true' and 'largely true', and only 49\% marked 'not true' or 'somewhat true').

With regard to the next statement about sexual harassment at school, we notice that almost all the results are on the same level. However, in Emmaboda, only 55\% of students marked 'not true' or 'somewhat true' about this statement. However, it is worth mentioning that in Emmaboda we can see a larger percentage of students who marked the 'I don't know' answer; as a result, other percentages are shown differently compared to the other cities. But again, Klaipeda has the highest percentage (13\%) of students who think that sexual harassment occurs in their school, which raises some questions about the general atmosphere in Klaipeda schools.

In the next statement, the aim was to find out whether the schools take action if a student bullies another student. We see not very promising results, especially in Gusev, where students (37\%) marked 'not true' or 'somewhat true'. This means that one third of the students think the school does not take action if one student bullies another. At the same time, we cannot see a very high level of security among students in the other cities. 


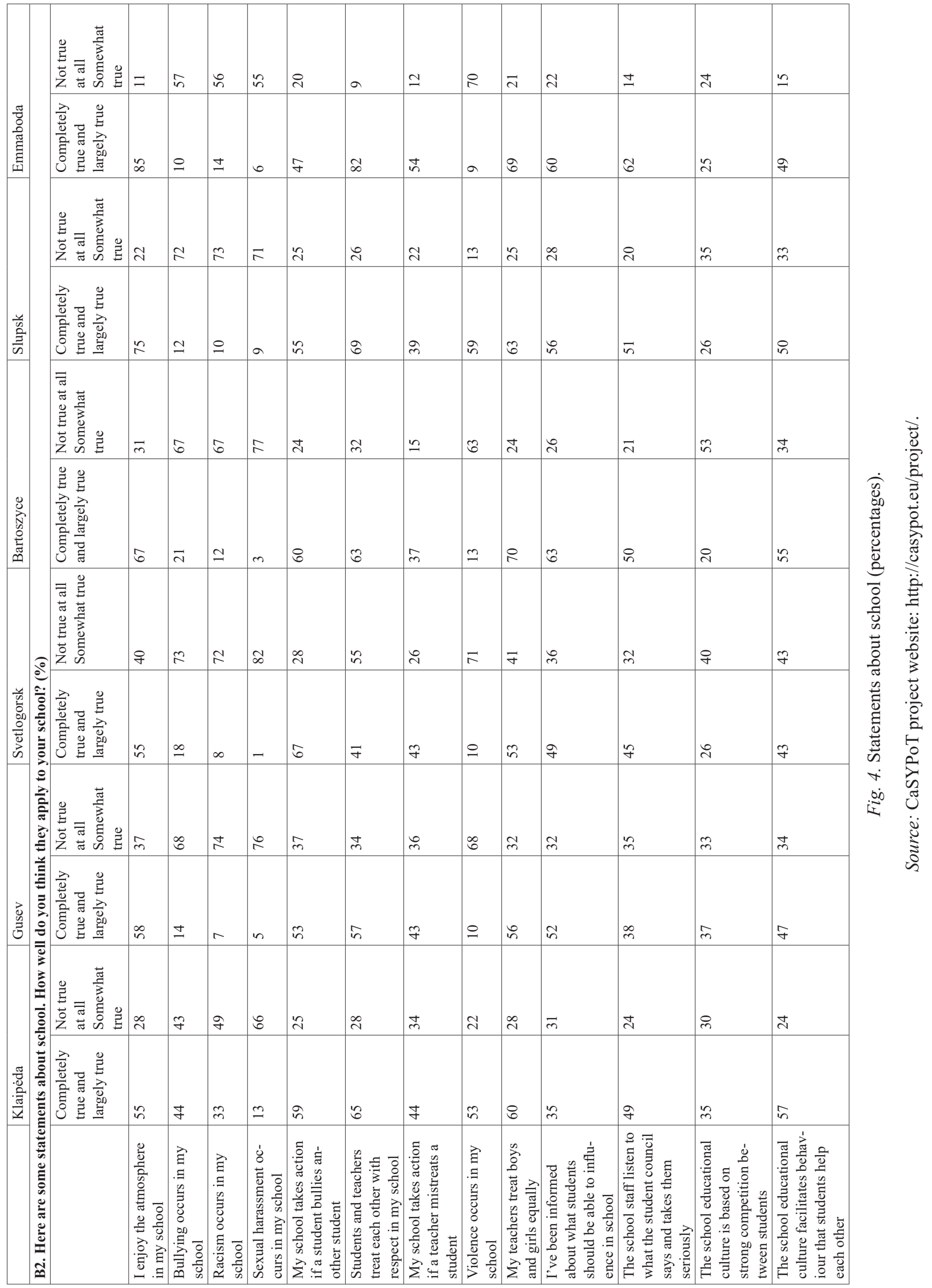


Regarding respectful treatment between students and teachers, we see a very promising result in Emmaboda, where $82 \%$ of the students marked 'true' and 'completely true'. This gives a positive view of the situation in Sweden. However, in Svetlogorsk the situation is the opposite. Most respondents (55\%) marked 'not true' or 'somewhat true', which means they think students and teachers do not treat each other with respect in their school. In Gusev, the situation is different, which shows that this is not the pattern for Russia, but only for Svetlogorsk. Other cities stand more or less at the same level; however, these results too are not very promising for students and teachers. Whatever stance a student takes, however, the teacher takes a central role in the classroom. Students always make choices by scrutinising the teacher's expectations, demands, and behaviour, even when the teacher encourages individual student activity or reorganises the class into peer work groups. This control is exerted by assignments, grades, minute-by-minute praise and correction, responses to different students' behaviour, or particular questions.

Another statement 'My school takes action if a teacher mistreats a student' goes together with the previous assumption. Only in Emmaboda (54\%) did students state that the school takes action if a teacher mistreats a student, whereas in the other cities this percentage is rather low (from $44 \%$ in Klaipeda to $37 \%$ in Bartoszyce).

The statement about violence (Violence occurs in my school) does not show Klaipeda in a good light (only $22 \%$ of students marked 'not true', and 53\% 'true' about violence at school). While Emmaboda again presents the highest results ( $70 \%$ indicated that violence does not occur at school).

On gender equality, we can see some small differences in Russian schools, where a slightly higher percentage of students stated that there were some inequalities at school. In Bartoszyce (70\%) and in Emmaboda (69\%), students gave positive feedback about gender equality in their schools.

The statement about information (I've been informed about what students should be able to influence in school) gives an overview of how students are informed, what information they have about their 'power' at school. Students in Klaipeda appear to have less information (35\%) than students in the other cities. The situations in Russia and Poland are more or less the same, while in Sweden again we can see better results, which gives a positive picture of the school situation for students in Emmaboda.

The next statement (The school staff listen to what the student council says and takes it seriously) is proof of this. In Emmaboda, 62\% agree that the school staff listen to what the student council says and take it seriously. The situation in Poland is also promising, while in Russia and Lithuania, students think the school staff do not really react to students' needs. The last two statements 'The school educational culture is based on strong competition between students' and 'The school educational culture facilitates behaviour so that students help each other' show that students in Klaipeda, Slupsk and Emmaboda think that they study in a helpful atmosphere, while in Gusev students (37\%) experience strong competition with each other.

\subsection{Students' influence on decision making at school}

The results show very interesting views of the school environment (climate) in the cities. We can see from the results that students in Emmaboda feel strong, having their own opinions at school. At the same time, they feel comfortable, since reports on bullying, sexual harassment and gender inequality are low in the city. The situation in Russian schools show differences between the two cities, where Svetlogorsk students enjoy the atmosphere at school much more than students in Gusev. In Poland, the situation is similar to Russia, only in Bartoszyce students give positive feedback about gender equality at their schools. In Klaipeda, we can see problems with bullying, sexual harassment and racism. Of course, these assumptions should be compared to other schools in other cities.

In fact, two questions 'How much do you want to be part of and decide about the following?' and 'How much do you feel you as a student are allowed to be a part of and decide when it comes to the following?' shows what the students want to influence. Both questions consist of ten statements:

1. What I will be learning

2. How we will work

3. The homework 
4. The exams

5. The schedule

6. The food

7. The school rules

8. The school environment (inside)

9. The school environment (outside)

10. The school's offer of free time activities

The answers were combined into two-tier results ('very little/rather little', and 'largely true/very much').

For a more interesting analysis, it is useful to look at both Figures 4 and 5 at the same time. At first glance, we can see the highest results for the statements 'What I will be learning', 'The exams' and 'The schedule'. In almost all the cities, we can see results ('largely true/very much') higher than $60 \%$. The highest results were in Svetlogorsk (92\% 'largely true/very much') for 'What I will be learning', while in the second table 'are allowed' Svetlogorsk students marked the highest 49\% 'largely true/very much'. This allows us to make the assumption that in this city students are given less influence than they want. In general, we can see that students would like to be part of the decision making process in their learning. At the same time, we can see Svetlogorsk students again wanting to decide to work (84\%) more than students in the other cities, but the analysis of what 'are allowed' (71\%) gives us the idea that they are also allowed more than in other cities. In Poland, students 'are allowed' less (61\% in Bartoszyce and 55\% in Slupsk marked 'very little' and 'rather little' about the ability to decide how to work).

The most important question for students in all countries was 'What I will be learning' On the whole, most interest was shown by students from Bartoszyce (89\%) and Svetlogorsk (92\%). In the responses about the ability to decide about the homework and exams, students in Svetlogorsk (71\% and $85 \%$ ), and in Emmaboda ( $79 \%$ and $79 \%$ ), would like to influence it more than in other cities. In Klaipeda, these two options are less important (52\% and 64\%) than in the other cities. Talking about the schedule and the ability to be part of the decision making process, the results are higher again in Svetlogorsk (82\%), Slupsk (79\%) and Bartoszyce (76\%).

The results also show that students are less interested in the school environment (both inside and outside) and school activities (except for Svetlogorsk, where the school environment inside is rather important, 73\% marked 'largely true/very much'). The lowest interest among all the answers is in the outside environment, and this is true for all the cities.

In the question 'How much do you feel you as a student are allowed to be a part of and decide when it comes to the following?' the results ('very little/rather little') are higher in Bartoszyce than the others. In Svetlogorsk, the results are much more promising, varying from $41 \%$ ('largely true/very much' that students are allowed to be part of and decide about the schedule) and 75\% ('largely true/very much' that students are allowed to be part of and decide about the school's offer of free time activities). However, we cannot find any tendencies according to countries, since cities in the same countries do not have similar results and are different in single answers. 


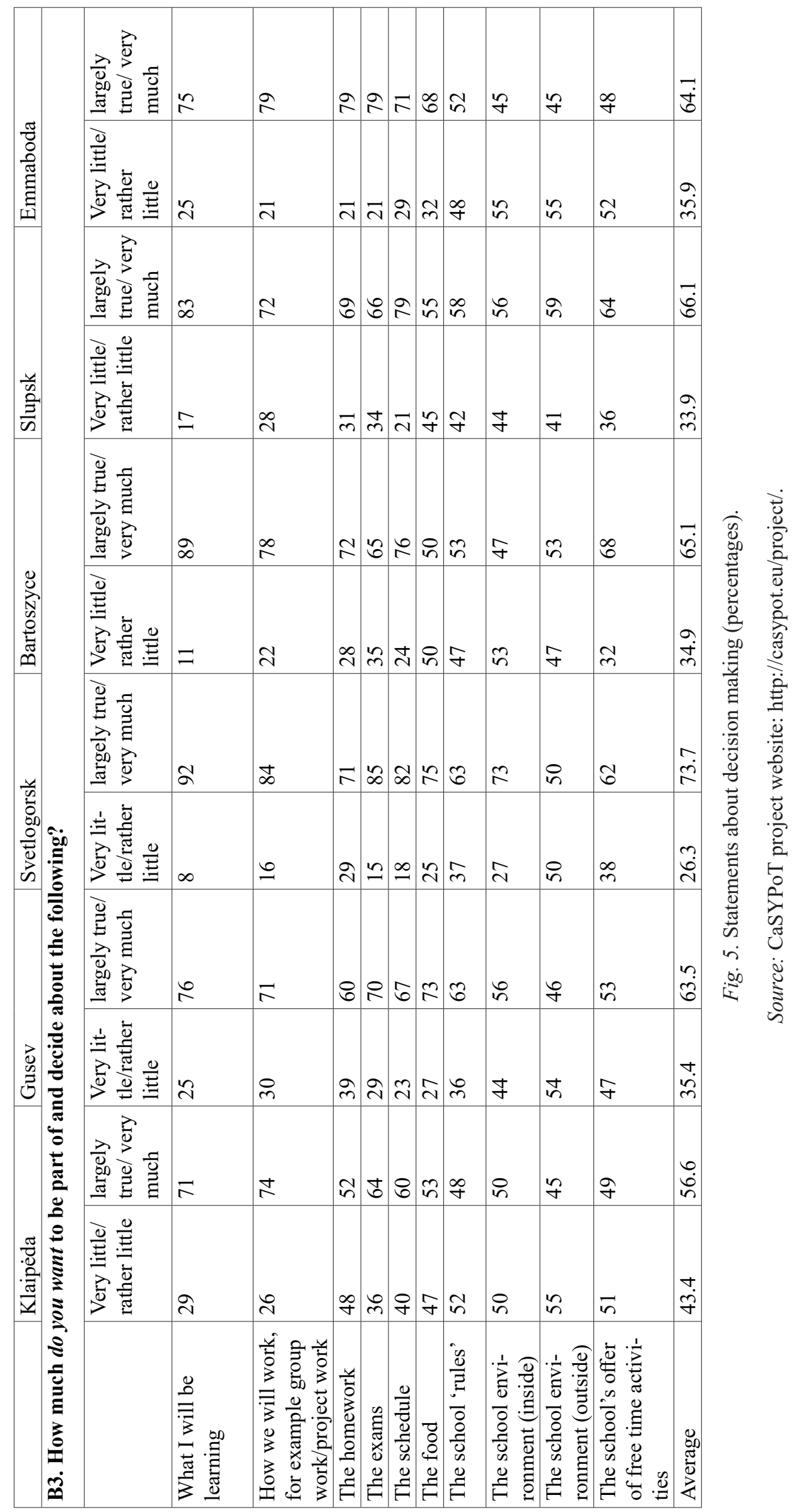




\begin{tabular}{|c|c|c|c|c|c|c|c|c|c|c|c|c|}
\hline \multicolumn{2}{|c|}{\begin{tabular}{l|l|} 
& Klaipèda \\
\end{tabular}} & & \multicolumn{2}{|c|}{ Gusev } & \multicolumn{2}{|c|}{ Svetlogorsk } & \multicolumn{2}{|c|}{ Bartoszyce } & \multicolumn{2}{|c|}{ Slupsk } & \multicolumn{2}{|c|}{ Emmaboda } \\
\hline \multicolumn{13}{|c|}{ B4. How much do you feel you as a student are allowed to be a part of and decide when it comes to the following? } \\
\hline & \begin{tabular}{|l} 
Very \\
little/rath- \\
er little
\end{tabular} & $\begin{array}{l}\text { largely } \\
\text { true/ very } \\
\text { much }\end{array}$ & $\begin{array}{l}\text { Very } \\
\text { little/ } \\
\text { rather } \\
\text { little }\end{array}$ & $\begin{array}{l}\text { largely } \\
\text { true/ very } \\
\text { much }\end{array}$ & $\begin{array}{l}\text { Very } \\
\text { little/ } \\
\text { rather } \\
\text { little }\end{array}$ & $\begin{array}{l}\text { largely } \\
\text { true/ } \\
\text { very } \\
\text { much }\end{array}$ & $\begin{array}{l}\text { Very } \\
\text { little/ } \\
\text { rather } \\
\text { little }\end{array}$ & $\begin{array}{l}\text { largely } \\
\text { true/ very } \\
\text { much }\end{array}$ & $\begin{array}{l}\text { Very } \\
\text { little/ } \\
\text { rather } \\
\text { little }\end{array}$ & $\begin{array}{l}\text { largely } \\
\text { true/ } \\
\text { very } \\
\text { much }\end{array}$ & $\begin{array}{l}\text { Very } \\
\text { little/ } \\
\text { rather } \\
\text { little }\end{array}$ & \begin{tabular}{|l} 
largely \\
true/ \\
very \\
much
\end{tabular} \\
\hline $\begin{array}{l}\text { What I will be } \\
\text { learning }\end{array}$ & 52 & 48 & 60 & 40 & 51 & 49 & 65 & 35 & 64 & 36 & 54 & 46 \\
\hline $\begin{array}{l}\text { How we will } \\
\text { work, for ex- } \\
\text { ample group } \\
\text { work/project } \\
\text { work }\end{array}$ & 53 & 47 & 40 & 60 & 29 & 71 & 61 & 39 & 55 & 45 & 43 & 57 \\
\hline The homework & 52 & 48 & 60 & 40 & 49 & 51 & 77 & 23 & 38 & 62 & 58 & 42 \\
\hline The exams & 47 & 53 & 55 & 45 & 40 & 60 & 77 & 23 & 72 & 28 & 56 & 44 \\
\hline The schedule & 53 & 47 & 60 & 40 & 59 & 41 & 82 & 18 & 70 & 30 & 68 & 32 \\
\hline The food & 58 & 42 & 54 & 46 & 44 & 56 & 85 & 15 & 70 & 30 & 77 & 23 \\
\hline $\begin{array}{l}\text { The school's } \\
\text { 'rules' }\end{array}$ & 55 & 45 & 60 & 40 & 47 & 53 & 84 & 16 & 72 & 28 & 75 & 25 \\
\hline $\begin{array}{l}\text { The school } \\
\text { environment } \\
\text { (inside) }\end{array}$ & 55 & 45 & 53 & 47 & 31 & 69 & 81 & 19 & 62 & 38 & 65 & 35 \\
\hline $\begin{array}{l}\text { The school } \\
\text { environment } \\
\text { (outside) }\end{array}$ & 60 & 40 & 53 & 47 & 31 & 69 & 80 & 20 & 61 & 39 & 72 & 28 \\
\hline $\begin{array}{l}\text { The school's } \\
\text { offer of free } \\
\text { time activities }\end{array}$ & 59 & 41 & 48 & 52 & 25 & 75 & 87 & 13 & 63 & 37 & 72 & 28 \\
\hline Average & 54.4 & 45.6 & 54.3 & 45.7 & 40.6 & 59.4 & 77.9 & 22.1 & 62.7 & 37.3 & 64 & 36 \\
\hline
\end{tabular}

Fig. 6. Statements about feelings of involvement (percentages).

Source: CaSYPoT project website: http://casypot.eu/project/.

To sum up, the tendencies described show some confusing situations. Moreover, it is impossible to draw a parallel between cities in the same country, and as a result the tendencies are unique to each city, but not the country in general. In general, Emmaboda shows much more promising results about the situation at school, but at the same time we can see that the average percentage of students' attitude about being part of decision making in the school is not very high. The situation in Klaipeda is more alarming: on one hand we can see that the school educational culture encourages students to help each other, but at the same time students indicate that bullying, racism and sexual harassment occur at school.

\section{Final remarks and recommendations}

The research specifically attempted to examine the school situation, to examine students' perception of school life, their motivation and engagement. In fact, motivation is seen as a prerequisite of and a necessary element for student engagement in learning. Student engagement in school life is not only an end in itself, it is also a means to an end for students to achieve sound academic results. This is important, because true engagement can lead to higher academic achievement throughout student life. If educators want to know and resolve young students' issues and make schools engaging places, then they actually have to listen to what students say about their classes and their teachers. In addition to being directly predictive of their results, student perceptions of the school climate may offset or counteract the negative impact of risk factors that increase the probability of behavioural and emotional problems. Furthermore, we can assume that student perceptions of a high-quality school climate offset the negative effects of self-criticism and low levels of self-efficacy. These insights indicate that although a perceived high-quality school climate is advantageous to all students, it may be particularly beneficial to students who are at risk of achieving negative results. In 
fact, we agree that schools are asked to shoulder an ever-increasing responsibility in raising students. The expectations of a teacher half a century ago did not include the responsibilities for students' social and emotional development that we now expect.

In conclusion, this survey reflects the opinions of young people on many aspects of school life, and reveals a high degree of interest in solving a range of problems. Moreover, the study describes the current situation in schools, which is essential for the development and evaluation of future prevention policies and interventions. It is very important for educators to understand the different types of extrinsic motivation, and how they may work, as they cannot always rely on intrinsic motivation to promote learning. Many of the classroom activities that a teacher wants students to do are not necessarily in themselves interesting or enjoyable. Therefore, using more active and volitional forms of extrinsic motivation, such as electronic media sources, are effective strategies for successful teaching. Parent communities, and political and social actors, can contribute to the creation of a positive school atmosphere, by showing teachers their appreciation for undertaking such a demanding job, and for being totally dedicated to it.

Recommendations:

- To create and implement a welcoming environment, atmosphere and climate in school;

- To create and implement more personalised, participatory and cooperative methods;

- To incorporate methods with informal and non-formal educational settings that enable the learner to develop personal skills, including critical and analytical thinking, creativity and learning;

- To engage students in a dialogue with the school authorities, in order to strengthen the participation of young people in schools, as a first step towards civil society involvement;

- To ensure that young people have access to citizenship education, to provide them with a sound knowledge of political systems, democracy and human rights, also attained through community-based experiences, in order to promote active civil participation;

- To encourage the development of self-awareness and less competitive mindsets, by fostering appreciation for individual skills and strengths;

- To strengthen exchange and networking between regions of the Baltic Euroregion, as a way of improving cooperation and breaking down stereotypes.

Note

The content of this article is the sole responsibility of the authors, and can in no way be taken to reflect the views of the European Union, the Managing Authority or the Joint Secretariat of the Interreg South Baltic Programme 2014-2020.

\section{References}

16-19 years old youth questionnaire Lupp. (Hansén, C., Skålmedal, J. (2015).Ungas livssituation i siffror. Lupp 2015 Emmaboda kommun, Fakulteten för samhällsvetenskap Utrednings-och forskningsservice Linnéuniversitetet). See online access: https://drive.google.com/a/dest.smk.lt/file/d/0B9KN_y33MqruVWRKZ0ZZdmVMSmc/view

Data for the Sustainable Development Goals. (2018). See online access: http://uis.unesco.org/en/topic/out-school-children-and-youth)

Dèl nacionalinés jaunimo politikos 2011-2019 metu plètros patvirtinimo. (2010) Gruodžio 1 d., Nr. 1715. See online access: https://e-seimas.lrs.lt/portal/legalAct/lt/TAD/TAIS.387971.

Galimybiu studija „,Klaipédos jaunimo situacijos tyrimas “ (2015). Klaipėda: Socialinių mokslų kolegija.

Ilgalaike jaunimo problematikos tyrimu koncepcija. (2010). See online access: http://www.jrd.lt/uploads/ES\%20I/Ilgalaike_jaunimo_prob.\%20koncepcija.pdf.

Youth 2030. (2018). Working with and for young people. See online access: https://www.un.org/youthenvoy/wp-content/uploads/2018/09/18-00080_UN-Youth-Strategy_Web.pdf

Jaunimo politikos igyvendinimo savivaldybėse kokybès vertinimas. (2012). Klaipédos miesto savivaldybės vertinimo ataskaita. See online access: http://www.jrd.lt/uploads/ES\%20I/GALUTINE\%20ATASKAITA\%20Klaipeda.pdf.

Jaunimo problemu sprendimo Klaipédos miesto savivaldybejje 2013-2018 m. planas. 
Jaunimo situacijos Kauno mieste tyrimas. (2011). See online access: http://vini.lt/wp-content/uploads/2011/03/Kaunomiesto-jaunimo-situacijos-tyrimas.pdf.

Early School Leaving, EU. See online access https://ec.europa.eu/education/policies/school/early-school-leaving_en

Lithuanian Youth Policy: Legislation, Structures, Good Practice.s (2013). See online access: http://www.jrd.lt/informacija-dirbantiems-su-jaunimu/metodiniai-leidiniai/el-biblioteka/jrd.pdf

Liukinevičienè, L. (2011). Youth Employment Policy Caree Guidance of School children in North-western Lithuania. Socialiniai tyrimai / Social Research, Vol. 4 (25), p. 64-74. ISSN 1392-3110. See online access: file://D:/Downloads/6102203.pdf.

McMillan, J., Schumacher, S. (2001). Research in education: A conceptual introduction. 5th ed. USA: Longman.

Nacionaline jaunimo politikos 2011-2019 metu plètros programa.

The Future of the Council of Europe Youth Policy: Agenda 2020.(2008). See online access: https://rm.coe.int/1680702428

UN-Youth-Strategy. (2018). Vol. 4. See online access: https://www.un.org/youthenvoy/wp-content/uploads/2018/09/18-00080_UN-Youth-Strategy_Web.pdf

Youth Wellbeing Survey. (2014). See online access: https:/www.cph.co.nz/wp-content/uploads/youthwellbeingsurvey2013.pdf

Reducing early school leaving: Key messages and policy support. Final Report of the Thematic Working Group on Early School Leaving. (2013). See online access: https://ec.europa.eu/education/sites/education/files/early-schoolleaving-group2013-report en.pdf

Zuoza, R. (2000). Jaunimo pilietinis iniciatyvos skatinimas Lietuvoje. Pedagogika, T. 40, p. 27.

What is school climate? by Aleksandra Loukas. (2007). Leadership Compass, Vol. 5, No. 1. See online access: https:// www.naesp.org/sites/default/files/resources/2/Leadership_Compass/2007/LC2007v5n1a4.pdf

\title{
TARPTAUTINIS LYGINAMASIS JAUNIMO (16-19) METU TYRIMAS: SITUACIJA MOKYKLOSE
}

\author{
Giedré StrakšienĖ, Aleksandra Batuchina \\ Klaipedos universitetas (Lietuva)
}

\section{Santrauka}

Straipsnyje analizuojama tyrimo dalis, vykdant projektą „Strateginès jaunimo politikos ir tarptautinio bendradarbiavimo stiprinimas“ (akronimas - CaSYPoT, Nr. STHB.05.01.00-SE-0024/15) pagal 2014-2020 m. INTERREG Pietų Baltijos programą. Bendrasis projekto siekinys: skatinti jaunimą įsitraukti į vietos bendruomenių demokratijos kūrimo ir valdymo procesus, išryškinant jaunų žmonių vaidmens svarbą visuomenès vystymosi kontekste. Vykdant CaSYPoT projektą, $2017 \mathrm{~m}$. balandžio-birželio mèn. parengtas ir atliktas jaunimo situacijos tyrimas (anketinè apklausa, adaptuotas LUPP klausimynas, kurio autoriai - C. Hansén ir J. Skålmedal (2015)) Pietų Baltijos regiono šalyse: Švedijoje, Lenkijoje, Rusijoje (Kaliningrado srityje) ir Lietuvoje. Atliekant longitudini tyrimą, viena klausimyno dalis buvo skirta jaunimo situacijai mokyklose nustatyti. Tikslas - atskleisti jaunimo situaciją ugdymo ịstaigose ir, taikant lyginamajį metodą, išryškinti pavienių savivaldybių ypatumus šiuo aspektu. Jaunuoliams pateikti klausimai, susiję su jų mokymosi aplinka: mokyklos atmosfera (klimatu), santykiais su bendraamžiais ir pedagogais, galimybėmis ir noru ịsitraukti ị mokymosi bei laisvalaikio veiklų organizavimą ugdymo įstaigoje, mokyklos savivaldą ir pan. Tyrimo grupę sudare 1593 jaunuoliai nuo 16 iki 19 metų amžiaus iš 6 savivaldybių: Emmabodos (Švedija), Slupsko ir Bartoszyce (Lenkija), Svetlogorsko ir Gusevo (Rusija, Kaliningrado sritis) bei Klaipėdos (Lietuva). Visose savivaldybėse respondentai pagal lyti pasiskirste tolygiai, išskyrus Svetlogorską, kur dominavo merginos (33\% vaikinų ir $67 \%$ merginų).

Daugiau kaip pusė apklaustų jaunuolių visose savivaldybėse mokyklos aplinką ịvardijo kaip patrauklią ir saugią teritoriją, teigè, kad jiems patinka ugdymo ịstaigos aplinka (klimatas). Lyginant pastebèta, kad Klai- 
pėdos ir Svetlogorsko jaunuoliai (55 \%) šiek tiek mažiau patenkinti mokyklos atmosfera, taip pat ir besimokantieji Emmabodoje (85 \%). Nemažai tiriamųų pripažino, kad vis dar susiduria su tokiomis problemomis kaip patyčios, priekabiavimas, prievarta, lyčių lygybės ar demokratijos principų nesilaikymas ar ryški konkurencija mokyklos aplinkoje. Didesnè dalis respondentų visose savivaldybėse atsakė, kad žino, kur kreiptis pagalbos mokykloje, esant patyčioms ar panašaus pobūdžio reiškiniams. Be to, tyrimas atskleidè, kad 16-19 metų jaunuolius labiausiai domina, ko ir kaip bus mokomasi mokykloje, kokie bus namų darbai, kaip bus sudarytas tvarkaraštis, kokie reikalavimai bus keliami egzaminams, bet jaučiasi nepakankamai informuoti, ar nesudaromos sąlygos dalyvauti planuojant šiuos procesus. Didžioji dalis jaunuolių tirtose savivaldybėse turi savo siekių ir pageidauja aktyvesnès įtraukties ị mokyklos bendruomenės veiklas: Svetlogorske (92\%), Bartoszyce (89 \%), Slupske (83 \%).

Aptartos tendencijos atskleidžia ir keletą kontraversiškų situacijų, kita vertus, suprantama, kad neimanoma nubrèžti paralelès tarp tos pačios šalies miestų, tad išryškejjusios tendencijos gali būti būdingos tik konkrečiam miestui, o ne šaliai. Ir, nors Emmabodos jaunimo situacija geriausia mokyklose, bet galima pastebèti, kad mokinių dalyvavimo priimant sprendimus mokykloje skaičius, lyginant su kitais miestais, nedidelis. Ir priešingai, nors Klaipėdos ugdymo ịstaigose skatinama pagarba, pagalba vienas kitam, tačiau kartu įžvelgiame, kad vis dar gajos patyčios ir priekabiavimo apraiškos. Apibendrindami galime teigti, kad lyginamasis tyrimas atskleide jaunų žmonių požiūrị, lūkesčius ir atkreipe dèmesị ị ịvairias problemas jų ugdymosi ịstaigose. Tikimès, kad tyrimo išvados ir rekomendacijos prisidès prie jaunimo politikos bei strategijos formavimo bei didins jaunosios kartos motyvaciją ir ịsitraukimą ị mokyklos bei visuomeninị gyvenimą.

PAGRINDINIAI ŽODŽIAI: mokykla, mokiniai, jaunimas, ugdymas, projektas “CaSYPoT. 